\title{
Phytanic acid attenuates insulin-like growth factor-1 activity via nitric oxide-mediated $\gamma$-secretase activation in rat aortic smooth muscle cells: possible implications for pathogenesis of infantile Refsum disease
}

\author{
Gursev S. Dhaunsi', Mayra Alsaeid' and Saghir Akhtar ${ }^{2}$
}

BACKGROUND: Infantile Refsum disease (IRD), a peroxisomal disease with defective phytanic acid oxidation, causes neurological impairment and development delay. Insulin-like growth factor-1 (IGF-1) regulates child development and to understand molecular mechanism(s) of IRD, we examined the effect of phytanic acid (PA) on IGF-1 activity.

METHODS: Bromodeoxyuridine (BrdU) incorporation was measured in rat aortic smooth muscle cell (SMC) cultures following treatment with fetal bovine serum (FBS), basic fibroblast growth factor (bFGF), platelet-derived growth factor (PDGF) or IGF-1 in the absence or presence of PA. Gene expression and protein contents of IGF-1 receptor (IGF-1R) and PDGF receptor (PDGFR) were examined using quantitative PCR and western blotting.

RESULTS: PA inhibited mitogenic activities of FBS, PDGF and IGF-1 with more pronounced effect on IGF-1-induced bromodeoxyuridine (BrdU) incorporation. Palmitic acid or lignoceric acids did not inhibit IGF-1 activity. PA had no effect on PDGFR mRNA/protein levels but markedly increased IGF-1R mRNA levels. PA and nitric oxide (NO) markedly decreased IGF-1R protein. L-NAME, a NO synthase inhibitor and DAPT, a $\boldsymbol{\gamma}$-secretase inhibitor, alleviated PA-induced decrease in IGF-1R protein. Both PA and NO donor increased $\boldsymbol{\gamma}$-secretase activity which was alleviated by L-NAME.

CONCLUSION: This study demonstrates that PA attenuates IGF-1 activity possibly through IGF-1R impairment and NO-mediated modulation of $\mathrm{Y}$-secretase activity.

nfantile Refsum disease (IRD) is a neurometabolic peroxisomal
biogenesis disorder characterized by accumulation of supra-
physiological amounts of phytanic acid in tissues and body fluids
of the patients due to impaired peroxisomal fatty acid oxida-
tion (1-3). Children with peroxisomal biogenesis disorders,
such as Zellweger syndrome and IRD have aberrant phytanic
acid metabolism and often experience severe clinical complica-
tions that range from growth retardation to neurological and cardiovascular anomalies $(2,4)$. In comparison to IRD, an early onset peroxisomal biogenesis disorder, where patients present developmental delay, mental retardation, neuropathy, sensorineural hearing loss, osteoporosis (5-8), classical Refsum disease is less severe and occurs in late childhood and adults often associated with retinitis pigmentosa, anosmia, deafness, ataxia, and polyneuropathy. Though, PA has been linked, for many years now, to development of certain peroxisomal disorders, yet molecular mechanisms in relation to PA-induced pathogenesis in children have remained unclear. Phytanic acid, a branched fatty acid, is now well known to be catabolized in mammalian cells through peroxisome enzyme system $(9,10)$. A major amount of circulating phytanic acid in humans comes from dietary sources such as meats and dairy products (11), and its metabolism was recognized to be vital for human health with the identification of peroxisomal disorders, such as Zellweger syndrome and Refsum disease. Idel and co-workers (12) have reported that supraphysiological levels of phytanic acid induce nitric oxide-mediated apoptosis in cultured vascular smooth muscle cells suggesting thereby that phytanic acid might have a role to play in regulation of smooth muscle cell growth in vivo. During perinatal, neonatal, and postnatal periods of human development, normal functioning of the vascular system is essential for growth and function of various organs and tissues, and it is not known clearly, as yet, if phytanic acid has any role to play in growth of vasculature during normal development or disease in children. We reported earlier that patients with Zellweger syndrome, a peroxisomal disorder with abnormally high serum levels of PA and very long chain fatty acids beside other biochemical defects, have an impaired DNA synthesis (13). Growth factors, such as growth hormone and Insulin-like growth factors (IGFs), that stimulate DNA synthesis during mitogenic activities, are key peptides for normal development of children (14) and a variety of illnesses and metabolic disorders are associated with altered circulating levels of insulin-like growth factor-1 (IGF-1) as well as insulin-growth factor binding proteins (15). Both in vivo and in vitro studies have shown that, besides numerous other biomolecules and metabolites, a variety

'Department of Pediatrics, Faculty of Medicine, Kuwait University, Kuwait; ${ }^{2}$ Department of Pharmacology and Toxicology, Faculty of Medicine, Kuwait University, Kuwait. Correspondence: Gursev S. Dhaunsi (dhaunsig@hsc.edu.kw)

Received 31 March 2016; accepted 9 October 2016; advance online publication 11 January 2017. doi:10.1038/pr.2016.258 


\section{Articles Dhaunsietal.}

of growth factors such as platelet-derived growth factor (PDGF), IGF-1, and fibroblast growth factor (FGF) and their receptors, are important for angiogenesis and normal growth of vasculature (16-18) as well. PDGF has a well-established role in eliciting a proliferative response in vascular smooth muscle cells and, like bFGF and IGF-1, much of this proliferative response occurs through receptor-mediated mitogenic signaling (19). PDGFR and IGF-1R are membrane associated receptor tyrosine kinases and binding of a ligand to the extracellular subunit has been shown to result in their trans-/activation and signal transduction $(20,21)$. Recent studies have revealed that IGF-1 signaling stimulates proliferation, survival and differentiation of various cells. In view of the importance of growth factors, particularly, IGF-1, in growth and development of children and, the reported development delay, mental retardation and other anomalies in patients with phytanic acid metabolism defect, this study was carried out in vascular smooth muscle cells to examine effect of PA on IGF-1 activity.

\section{METHODS}

Male Wistar Rats (weighing 100-125 g) were used in this study according to the United States National Institute of Health (NIH) guidelines for the Care and Use of Laboratory Animals (NIH Publication No. 85-23, revised in 1996). The study protocols were approved by the Research Ethics Committee of Health Sciences Center, Kuwait University (MK 01/12).

\section{Materials}

Bovine serum albumin, penicillin/streptomycin, fetal bovine serum (FBS), elastase, and collagenase were purchased from Sigma Chemical Company (St. Louis, MO). Dulbecco's Modified Eagle Medium (DMEM)-Ham's F-12 (1:1) trypsin and Ethylenediaminetetraacetic acid were from GIBCO (Grand Island, NY). SNAP, and phytanic acid were purchased from Sigma Chemical whereas DAPT $(\mathrm{N}-((3,5-$ Difluorophenyl)acetyl)-L-alanyl-2-phenyl)glycine-1,1-dimethylethyl ester) was from Tocris Bioscience, Minneapolis, MN. PDGF, b-FGF and IGF-1 were procured from GIBCO. Antibodies used in this study were procured from Abcam (Cambridge, MA). Primaria tissue culture plates were obtained from Falcon Becton Dickinson (Oxnard, CA). All other reagents were of highest quality available and purchased from Sigma or Calbiochem (La Jolla, CA).

\section{Cell Culture and Biochemical Studies}

Aortic smooth muscle cell cultures. Rats were anesthetized with metofane and sacrificed by ventricular puncture for the removal of thoracic aortae. Aortic smooth muscle cells were cultured using enzymic digestion of aortic tissue by collagenase and elastase. Thoracic aortas were cleaned of the adherent fatty tissue and washed with sterile Hank's medium. Aortas were then incubated for $20 \mathrm{~min}$ at $37^{\circ} \mathrm{C}$ in the digestion mixture that contained $1.5 \mathrm{mg} / \mathrm{ml}$ bovine serum albu$\mathrm{min}, 25 \mathrm{U} / \mathrm{ml}$ of pancreatic Elastase and $200 \mathrm{U} / \mathrm{ml}$ Collagenase (type IX). After the incubation period, adventitia was removed and the medial layer was cut into small fragments and digested by incubation in digestion mixture for another $45 \mathrm{~min}$ followed by washing twice with fresh DMEM and centrifugation. Isolated cells were suspended in DMEM-F12 HAM containing 10\% heat-inactivated fetal bovine serum and plated onto $25 \mathrm{~cm}^{2}$ culture flasks for culture in humidified conditions under $5 \% \mathrm{CO}_{2}$. The obtained RASMC were characterized by immunostaining with monoclonal antibody specific for smooth muscle $\alpha$-actin (22).

Treatment of cell cultures. Aortic smooth muscle cells grown in culture plates were used in all experiments. Before adding the experimental agents, cell monolayers were washed twice with serum-free DMEM-F/12 medium (SFM) and incubated at $37^{\circ} \mathrm{C}$ in a humidified cell culture incubator for $2 \mathrm{~h}$ in the presence of $0.1 \%$ FBS containing
DMEM-F/12 medium. Phytanic acid concentrations used in this study were chosen based on the reported in vitro studies (12) to avoid cytotoxic effect and ranged from physiological (less than $2.5 \mu \mathrm{g} / \mathrm{ml}$ ) to supraphysiological (more than $2.5 \mu \mathrm{g} / \mathrm{ml}$ ) levels but less than those reported in serum/plasma of Refsum disease patients. Cytotoxic effect of phytanic acid was checked by counting the percentage of dead cells following treatment of cell cultures for 24-72 h. Phytanic acid $(0-10 \mu \mathrm{g} / \mathrm{ml})$ was mixed with $\alpha$-cyclodextrin-containing Dimethyl sulfoxide $(0.001 \% \mathrm{v} / \mathrm{v})$ and added to the cell cultures in the presence or absence of FBS (5\%), PGDF (50 ng/ml), IGF-1 $(50 \mathrm{ng} / \mathrm{ml})$, or FGF $(50 \mathrm{ng} / \mathrm{ml})$. Following the addition of experimental agents, cells were incubated in cell culture incubator for another $20-24 \mathrm{~h}$ at $37^{\circ} \mathrm{C}$.

BrdU incorporation. DNA synthesis in aortic smooth muscle cells in response to growth factors was assayed via measuring BrdU incorporation in to cellular DNA using kits purchased from Calbiochem.

RNA isolation and reverse transcription. In each experiment, total RNA was extracted from cultured smooth muscle cells with RNA extraction kit based on use of guanidinium thiocyanate, lithium chloride, and cesium triflouroacetate. Isolated RNA was of high quality and was used immediately for synthesis of first strand cDNA according to protocols from Clonetech's SMART PCR cDNA synthesis kit.

Quantitative PCR detection of $m R N A$ for PDGFR and IGF-1R. After the first-strand synthesis, real-time PCR was done using $8 \mu \mathrm{l}$ cDNA, $10 \mu$ l SYBR green PCR master mix (Bio-Rad Laboratories, Hercules, CA) and forward and reverse primers $(10 \mu \mathrm{mol} / \mathrm{l} / \mathrm{ml})$ (Integrated DNA Technologies, San Diego, CA) in a real-time PCR system (CFX96; Bio-Rad Laboratories). The primer sequences used were IGF-1R; forward 5'-GGGAATGGAGTGCTGTATG-3', reverse $5^{\prime}$-CACAGAAGCTTCGTTGAGAA- $3^{\prime}$ and PDGFR $\beta$; forward, $5^{\prime}$-C AACATTTCGAGCACCTTTGT- ${ }^{\prime}$, and reverse, 5' $^{\prime}$-AGGGCACTCC GAAGAGGTAA- $3^{\prime}$,. The specificity of the primers was analyzed by running a melting curve. The PCR cycling conditions used were $5 \mathrm{~min}$ at $95^{\circ} \mathrm{C}$ for initial denaturation, 40 cycles of $30 \mathrm{~s}$ at $95^{\circ} \mathrm{C}, 30 \mathrm{~s}$ at $58^{\circ} \mathrm{C}$ and $30 \mathrm{~s}$ at $72^{\circ} \mathrm{C}$. Each real-time PCR was carried out using three individual samples in triplicates, and the threshold cycle values were averaged. Calculations of relative normalized gene expression were done using the Bio-Rad CFX manager software.

Western blotting. Cell homogenates were prepared and SDSpolyacrylamide gel electrophoresis (SDS-PAGE) was performed using Laemelli's sample buffer. Following SDS-PAGE, proteins were transferred on to nitrocellulose and immunoblotted with antibodies against PDGFR, IGF-1R, and actin. Protein bands were visualized using horse raddish peroxidase (HRP)-labeled secondary antibody and ECL reagents.

Amount of protein in cell homogenates was measured using Protein assay kit from Bio-Rad.

Nitrite levels. Levels of nitrites, and index of NO generation, were measured in serum and cell culture supernatants using Greiss reaction assay according to the kit purchased from Calbiochem.

Assay of -secretase activity. Enzymic activity of $\gamma$-secretase was measured as described earlier (23) with slight modifications. RASMC homogenates were passed through a fine needle syringe and the membrane preparation was then used to measure enzyme activity by incubation in assay buffer containing $0.25 \%$ CHAPSO and fluorogenic peptide probe in the presence or absence of $\gamma$-secretase inhibitor, DAPT. Fluorescence was measured using a plate reader with $355 \mathrm{~nm}$ (excitation) and $440 \mathrm{~nm}$ (emission) wavelengths.

Data analysis. Values shown in the results are mean \pm SD of four experiments carried out in triplicate. Student's $t$-test was employed using SPSS software to determine statistical significance of the results.

\section{RESULTS}

Effect of Phytanic Acid on Growth Factor-Induced DNA Synthesis in Rat Aortic Smooth Muscle Cells

In order to examine the effect of PA on growth factor activity, BrdU incorporation was measured, as an index of DNA 


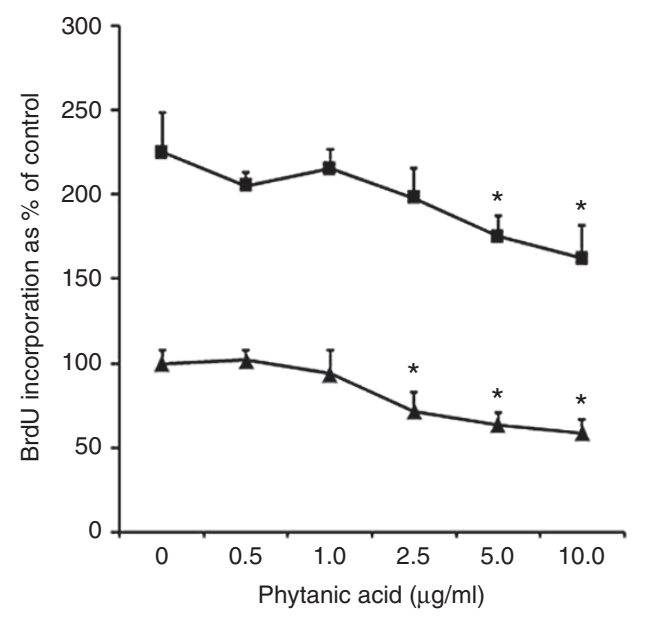

Figure 1. Bromodeoxyuridine incorporation (shown as percent of Control) into DNA of rat aortic smooth muscle cells following $24 \mathrm{~h}$ treatment with various concentrations $(0-10 \mu \mathrm{g} / \mathrm{ml})$ of phytanic acid in absence (triangles) or presence of $5 \%$ fetal bovine serum (squares). Values presented are mean \pm SD of six determinations carried out in duplicate. ${ }^{*} P<0.01$ when compared with control $(0 \mu \mathrm{g} / \mathrm{ml}$ of phytanic acid with or without FBS).

synthesis, in RASMC cultures following stimulation with FBS, PDGF, bFGF or IGF-1. Figure 1 shows that RASMC had a significantly $(P<0.01)$ reduced BrdU incorporation into DNA when treated with supra-physiological concentrations (5.0-10 $\mu \mathrm{g} / \mathrm{ml}$ ) of PA for $24 \mathrm{~h}$ in the presence of $5 \%$ FBS. PA-induced effects were more pronounced in a mitogen-deficient medium where $2.5 \mu \mathrm{g} / \mathrm{ml}$ of PA caused a significant impairment in DNA synthesis (Figure 1). Sub-/physiological concentrations (0.5$1.0 \mu \mathrm{g} / \mathrm{ml}$ ) of PA were found to exert no significant effect on DNA synthesis in the presence or absence of FBS. DNA synthesis in response to stimulation of RASMC by PDGF (Figure 2b) was significantly inhibited by PA $(5 \mu \mathrm{g} / \mathrm{ml})$. Interestingly, IGFinduced DNA synthesis was more profoundly affected by PA with significant inhibition at sub-/supraphysiological concentrations $(1.0-5.0 \mu \mathrm{g} / \mathrm{ml})$ of PA (Figure 2a). Treatment of RASMC with PA did not have any significant effect on b-FGFinduced DNA synthesis (Figure 2c). In order to examine, if the observed impairment of IGF-1 activity was selective for PA, SMC were treated with palmitic acid and lignoceric acid as well. Figure 3 shows that unlike PA, palmitic acid had no marked effect on basal BrdU incorporation but significantly enhanced IGF-1-induced mitogenesis. Lignoceric acid did not have any significant on basal or IGF-1-induced BrdU incorporation. Cytotoxic effect of the highest concentration (10 $\mu \mathrm{g} / \mathrm{ml}$ ) of PA used in this study in the absence of any growth factor was minimal after $24 \mathrm{~h}$ of incubation with less than $4 \%$ $(3.44 \pm 0.36 \%)$ of the cells found dead.

\section{Effect of Phytanic Acid on PDGFR, IGF-1R, Nitric Oxide, and $\gamma$-Secretase}

To examine if the observed PA-induced significant impairment of the mitogenic activity of PDGF and IGF-1 was receptor-mediated, gene expression and protein content of PDGFR and IGF-1R was measured using real time quantitative-PCR (qPCR) and western

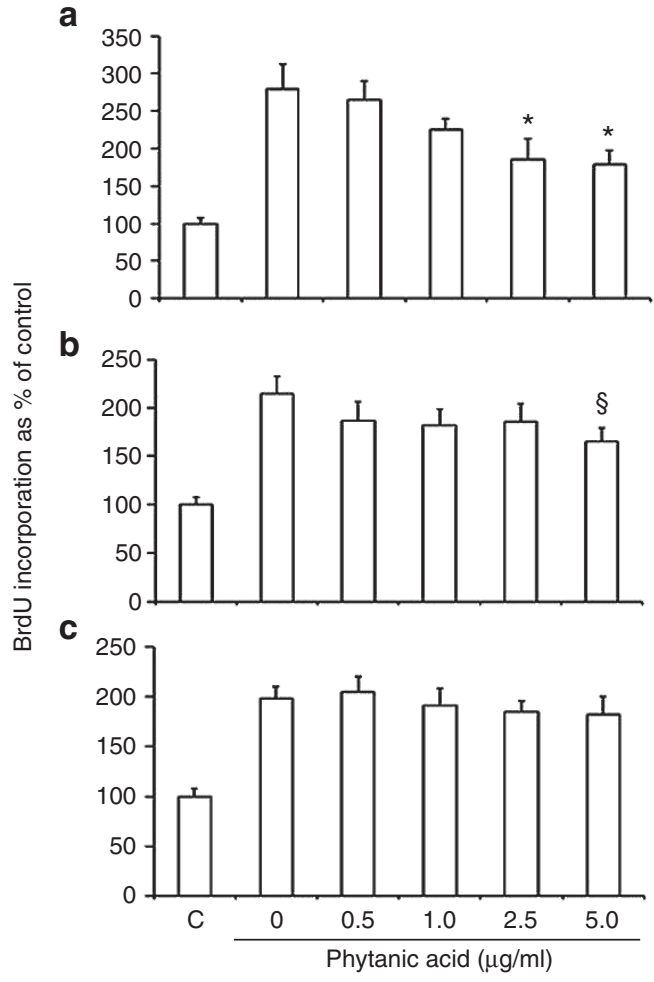

Figure 2. Effect of phytanic acid on BrdU incorporation in RASMC following $24 \mathrm{~h}$ treatment in the presence or absence of IGF-1 (a), PDGF (b) or b-FGF (c) in the absence or presence of phytanic acid $(0-5.0 \mu \mathrm{g} / \mathrm{ml})$. Values presented are mean $\pm \mathrm{SD}$ of six determinations carried out in duplicate. ${ }^{*} P<0.01$ when compared with IGF-treated cells and $0 \mu \mathrm{g} / \mathrm{ml}$ of phytanic acid. $\S P<0.05$ when compared with PDGF-treated cells and $0 \mu \mathrm{g} / \mathrm{ml}$ of phytanic acid. $C$ represents cells without any treatment with growth factor or phytanic acid.

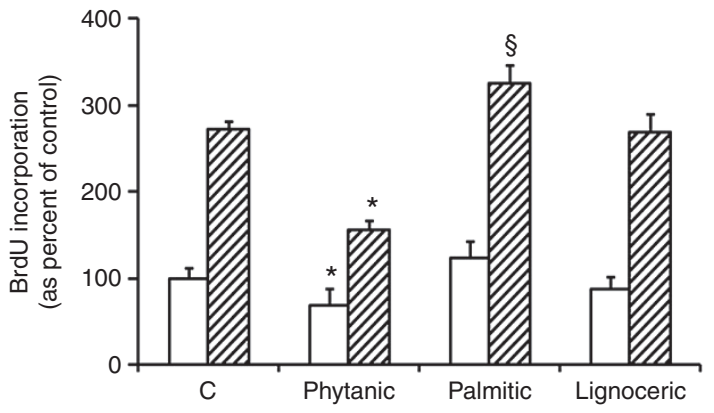

Figure 3. Bromodeoxyuridine incorporation (shown as percent of Control) into DNA of rat aortic smooth muscle cells following $24 \mathrm{~h}$ treatment with phytanic acid or palmitic acid or lignoceric acid in absence (open bars) or presence of $50 \mathrm{ng} / \mathrm{ml}$ of IGF-1 (shaded bars). Values presented are mean \pm SD of six determinations carried out in duplicate. ${ }^{*} P<0.01$ (phytanic acid) and $\S P<0.05$ (palmitic acid) when compared with control (without fatty acid treatment).

blotting, respectively. PA $(2.5-5.0 \mu \mathrm{g} / \mathrm{ml})$ did not have any significant effect on mRNA levels of PDGFR whereas IGF-1R mRNA levels were significantly increased (Figure 4a). Protein content of PDGFR remained unaltered in PA-treated RASMC, however IGF-1R protein levels (Figure $4 \mathrm{~b}$ ) shown as a ratio of IGF-1R/ actin were significantly $(P<0.01)$ decreased following treatment with PA $(2.5 \mu \mathrm{g} / \mathrm{ml}$ and above $)$. Figure 5 shows that cotreatment of RASMC with L-NAME or DAPT markedly prevented PA-induced 
a

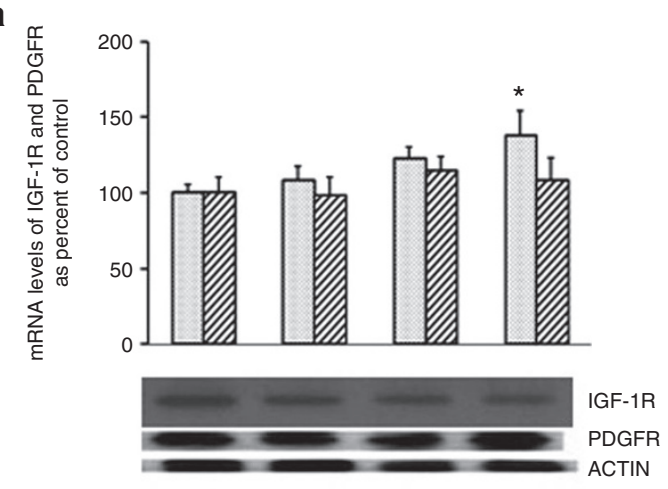

b

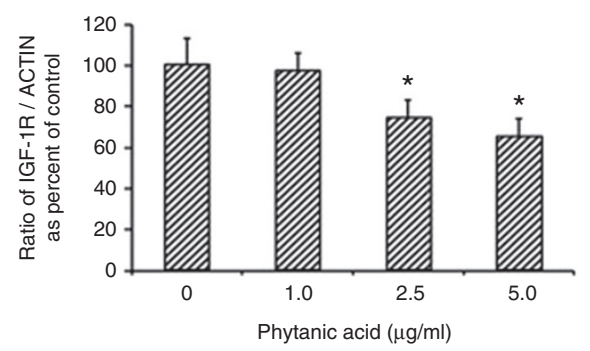

Figure 4. Gene expression and protein content of IGF-1 receptor and PDGFR in RASMC following a $24 \mathrm{~h}$ treatment with phytanic acid $(0-5.0 \mu \mathrm{g} /$ $\mathrm{ml}$ ). (a) The mRNA levels of IGF-1R (light bars) and PDGFR (dark shaded bars) as percent of control. (b) The representative western blots of IGF-1R, PDGFR and actin, and the band density ratio of IGF-1R/actin as percent of control. Values presented are mean $\pm \mathrm{SD}$ of four determinations. ${ }^{*} P<0.01$ when compared with control $(0 \mu \mathrm{g} / \mathrm{ml}$ of phytanic acid).

a

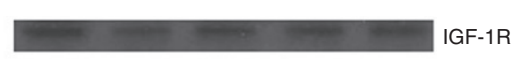

b

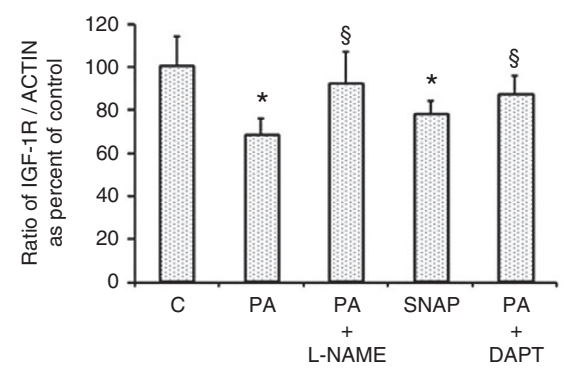

Figure 5. Ratio of IGF-1R protein and actin (shown as percent of control in lightly shaded bars) in RASMC treated for $24 \mathrm{~h}$ with PA $(5.0 \mu \mathrm{g} / \mathrm{ml})$ in the absence or presence of L-NAME $(100 \mathrm{mmol} / \mathrm{l})$ or DAPT $(100 \mu \mathrm{mol} / \mathrm{l})$ or following treatment with SNAP $(100 \mu \mathrm{mol} / \mathrm{l})$ alone. Values presented in the bar diagram are mean \pm SD of four determinations. ${ }^{*} P<0.01$ when compared with control (without any treatment). $\S P<0.05$ when compared with PA-treated cells.

decrease in IGF-1R protein content suggesting that $\mathrm{NO}$ generation and $\gamma$-secretase, a proteolytic enzyme, might have a role to play in downregulation of IGF-1R protein. Supraphysiological concentrations of PA were observed to significantly $(P<0.01)$ increase the accumulation of nitrites in culture media (Figure 6). Figure 7 shows that PA $(5 \mu \mathrm{g} / \mathrm{ml})$ and SNAP $(100 \mu \mathrm{mol} / \mathrm{l})$, a NO donor, significantly $(P<0.01)$ increased the enzyme activity of $\gamma$-secretase in RASMC and cotreatment of cells with L-NAME significantly prevented PA-induced activation of $\gamma$-secretase.

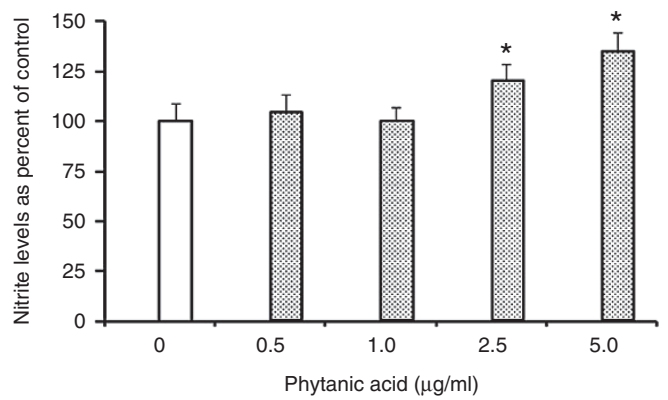

Figure 6. Levels of nitrites in cell culture supernatants of RASMC following $24 \mathrm{~h}$ treatment with phytanic acid $(0-5.0 \mu \mathrm{g} / \mathrm{ml})$. Values presented are mean \pm SD of six determinations. ${ }^{*} P<0.01$ when compared with control (cells without any treatment).

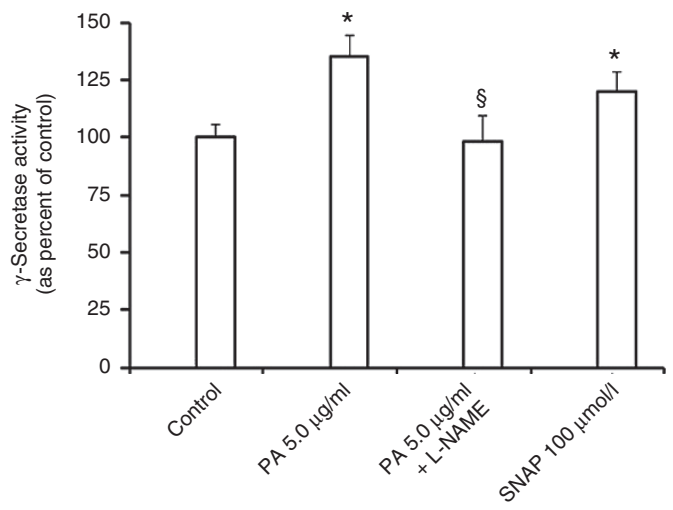

Figure 7. Effect of PA $(5.0 \mu \mathrm{g} / \mathrm{ml})$ and SNAP $(100 \mu \mathrm{mol} / \mathrm{l})$, NO donor on the enzymic activity of $\gamma$-secretase in RASMC. NOS inhibitor, L-NAME (100 $\mathrm{mmol} / \mathrm{l})$, prevents PA-induced activation of $\gamma$-secretase. Data are mean \pm SD of six measurements. ${ }^{*} P<0.01$ when compared with control (cells without any treatment). $\S P<0.05$ when compared with PA-treated cells.

\section{DISCUSSION}

A marked increase in the levels of phytanic acid in tissues and body fluids of patients with Refsum disease has, for many years, implicated this branched fatty acid in the development and progression of the disease, yet the exact mechanism of PA-induced pathogenesis have remained elusive. Our results show an impairment of growth factor activity by PA, particularly profound inhibition of IGF-1-induced mitogenesis through NO-mediated activation of $\gamma$-secretase in vascular smooth muscle cells. This study demonstrates receptor-mediated modulation of IGF-1 function by phytanic acid thereby highlighting the significance of growth factors and their possible role in development and progression of peroxisomal diseases.

Our findings that phytanic acid inhibits DNA synthesis in SMC suggest its role as a growth-retardant in vascular system. Fatty acids have been reported earlier to exert variable effects on growth of vascular smooth muscle cells depending upon the carbon chain length, saturation, and branching $(24,25)$. Though unbranched fatty acids have been shown in several reports to promote proliferation of smooth muscle cells, however others have reported fatty acids to induce apoptosis (26), and these contradicting reports highlight variations in concentrations of the fatty acids used and duration of their exposure 
to the cells. Though several studies related to the effect of fatty acids on vascular smooth muscle cell growth appear in the literature (27), our study documents the first report on selective impairment of IGF-1-induced DNA synthesis by phytanic acid. The fact that phytanic acid impaired IGF-1-induced DNA synthesis more profoundly in comparison to its effect on FBS-, PDGF-, or FGF-induced BrdU incorporation in cultures of SMC strongly indicates that phytanic acid has a selective mechanism in regulation of growth factor actions. Growth factor-induced mitogenic effects are regulated by their receptors and subsequent signaling events. Our findings that PA treatment had no marked effect on PDGFR protein expression but markedly reduced the protein levels of IGF-1R clearly demonstrates selectivity of PA to regulate growth factor activity at the receptor level. A significant overexpression of IGF-1R mRNA following PA treatment could be a compensatory response to the impaired IGF-1R protein content. It is an intriguing observation that IGF-1R protein is selectively depleted by PA treatment and suggests that IGF-1R may likely be undergoing degradation.

Besides several other mechanisms suggested for regulation of cellular functions by different fatty acids, intracellular production of or exposure to extracellular cytokines, reactive oxygen species, and nitric oxide production have been reported to mediate fatty acid-induced effects on cell survival (28-30). The supraphysiological concentrations of phytanic acid have been shown earlier to enhance nitric oxide production in vascular smooth muscle cells and induce apoptosis (12). Nitric oxide is an important regulator of vascular function and its overproduction has been widely reported to inhibit vascular growth in $v i v o$ as well as in cell culture studies (31). Our findings that treatment of SMC with SNAP, a NO donor, significantly decreased IGF-1R protein and cotreatment of RASMC with L-NAME, a NO synthase inhibitor, significantly prevented PA-induced depletion of IGF-1R protein strongly suggest an involvement of NO in degradation of IGF-1R protein. Intramembrane proteolysis of IGF-1R has been reported earlier where $\gamma$-secretase, a large and multiunit complex protease, cleaves the carboxyl terminal domain of IGF-1R during post-translational modification during Notch signaling (32). Our observation that DAPT, a $\gamma$-secretase inhibitor, partly alleviated PA-induced IGF-1R protein depletion strongly indicates an involvement of $\gamma$-secretase in downregulation of IGF-1R protein in this study. Though significance of the reported IGF-1R proteolysis during Notch-regulated cell signaling remains unclear, our findings suggest a possible new role for PA and NO in Notch cell signaling. Both PA and NO donor significantly increased the enzymatic activity of $\gamma$-secretase further strengthening our notion that PA selectively degrades IGF-1R protein through NO production and activation of $\gamma$-secretase. These findings provide a new direction for exploring molecular mechanisms of metabolic disorders and highlight the significance of growth factors and their receptors in development and progression of peroxisomal disorders of phytanic acid metabolism defect. It is important to mention that the scope of this study is centered on vascular smooth muscle cells and the observed effect of NO on $\gamma$-secretase and IGF-1R might also have implications in several other pathophysiological conditions such as diabetes, cancer, atherosclerosis, and hypertension where NO has been shown to actively participate (33). In view of the fact that IGF-1 plays an important role in growth and development during early childhood, findings of this study might have some implications for pathogenic events of IRD.

\section{ACKNOWLEDGMENT}

Authors would like to thank Nini Mathews, Heba Dalvi, and B.S. Srivastava for their technical assistance.

\section{STATEMENT OF FINANCIAL SUPPORT}

This study was supported by a research grant (MK 01/12) from Research Sector, Kuwait University.

Disclosure: Authors do not have any conflict of interests.

\section{REFERENCES}

1. Wierzbicki AS. Peroxisomal disorders affecting phytanic acid alpha-oxidation: a review. Biochem Soc Trans 2007;35(Pt 5):881-6.

2. Van Veldhoven PP. Biochemistry and genetics of inherited disorders of peroxisomal fatty acid metabolism. J Lipid Res 2010;51:2863-95.

3. Krause C, Rosewich H, Gärtner J. Rational diagnostic strategy for Zellweger syndrome spectrum patients. Eur J Hum Genet 2009;17:741-8.

4. Poll-The BT, Gootjes J, Duran M, et al. Peroxisome biogenesis disorders with prolonged survival: phenotypic expression in a cohort of 31 patients. Am J Med Genet A 2004;126A:333-8.

5. Wanders RJ, Jansen GA, Skjeldal OH. Refsum disease, peroxisomes and phytanic acid oxidation: a review. J Neuropathol Exp Neurol 2001;60: 1021-31.

6. Poll-The BT, Saudubray JM, Ogier H, et al. Infantile Refsum's disease: biochemical findings suggesting multiple peroxisomal dysfunction. J Inherit Metab Dis 1986;9:169-74.

7. Scotto JM, Hadchouel M, Odievre M, et al. Infantile phytanic acid storage disease, a possible variant of Refsum's disease: three cases, including ultrastructural studies of the liver. J Inherit Metab Dis 1982;5:83-90.

8. Budden SS, Kennaway NG, Buist NR, Poulos A, Weleber RG. Dysmorphic syndrome with phytanic acid oxidase deficiency, abnormal very long chain fatty acids, and pipecolic acidemia: studies in four children. J Pediatr 1986;108:33-9.

9. van den Brink DM, Wanders RJ. Phytanic acid: production from phytol, its breakdown and role in human disease. Cell Mol Life Sci 2006;63:1752-65.

10. Wanders RJ, Komen J, Ferdinandusse S. Phytanic acid metabolism in health and disease. Biochim Biophys Acta 2011;1811:498-507.

11. Hellgren LI. Phytanic acid-an overlooked bioactive fatty acid in dairy fat? Ann N Y Acad Sci 2010;1190:42-9.

12. Idel S, Ellinghaus $P$, Wolfrum $C$, et al. Branched chain fatty acids induce nitric oxide-dependent apoptosis in vascular smooth muscle cells. J Biol Chem 2002;277:49319-25.

13. Dhaunsi GS, Rahbeeni Z, al-Essa M, Ozand PT. Impaired DNA synthesis in dermal fibroblasts from Zellweger syndrome patients. J Inherit Metab Dis 1998;21:179-80.

14. Le Roith D. Seminars in medicine of the Beth Israel Deaconess Medical Center. Insulin-like growth factors. N Engl J Med 1997;336:633-40.

15. Collett-Solberg PF, Cohen P. The role of the insulin-like growth factor binding proteins and the IGFBP proteases in modulating IGF action. Endocrinol Metab Clin North Am 1996;25:591-614.

16. Hellberg C, Ostman A, Heldin CH. PDGF and vessel maturation. Recent Results Cancer Res 2010;180:103-14.

17. Tomanek RJ, Hansen HK, Christensen LP. Temporally expressed PDGF and FGF-2 regulate embryonic coronary artery formation and growth. Arterioscler Thromb Vasc Biol 2008;28:1237-43.

18. Delafontaine P. Insulin-like growth factor I and its binding proteins in the cardiovascular system. Cardiovasc Res 1995;30:825-34.

19. Nilsson J, Ksiazek T, Heldin CH, Thyberg J. Demonstration of stimulatory effects of platelet-derived growth factor on cultivated rat arterial smooth 


\section{Articles | Dhaunsietal.}

muscle cells. Differences between cells from young and adult animals. Exp Cell Res 1983;145:231-7.

20. Schlessinger J. Cell signaling by receptor tyrosine kinases. Cell 2000;103:211-25.

21. Laviola L, Natalicchio A, Giorgino F. The IGF-I signaling pathway. Curr Pharm Des 2007;13:663-9.

22. Dhaunsi GS, Hassid A. Atrial and C-type natriuretic peptides amplify growth factor activity in primary aortic smooth muscle cells. Cardiovasc Res 1996;31:37-47.

23. Hatch E, Morrow D, Liu W, Cahill PA, Redmond EM. Ethanol inhibits $\gamma$-secretase proteolytic activity in vascular smooth muscle cells. Alcohol Clin Exp Res 2015;39:2115-22.

24. Moreno JJ, Mitjavila MT. The degree of unsaturation of dietary fatty acids and the development of atherosclerosis (review). J Nutr Biochem 2003;14:182-95.

25. Hirafuji M, Machida T, Hamaue N, Minami M. Cardiovascular protective effects of $n-3$ polyunsaturated fatty acids with special emphasis on docosahexaenoic acid. J Pharmacol Sci 2003;92:308-16.

26. Diep QN, Intengan HD, Schiffrin EL. Endothelin-1 attenuates omega3 fatty acid-induced apoptosis by inhibition of caspase 3. Hypertension 2000;35(1 Pt 2):287-91.
27. Egan BM, Greene EL, Goodfriend TL. Nonesterified fatty acids in blood pressure control and cardiovascular complications. Curr Hypertens Rep 2001;3:107-16.

28. Hirafuji M, Machida T, Tsunoda M, Miyamoto A, Minami M. Docosahexaenoic acid potentiates interleukin-1beta induction of nitric oxide synthase through mechanism involving p44/42 MAPK activation in rat vascular smooth muscle cells. Br J Pharmacol 2002;136:613-9.

29. Naseem KM. The role of nitric oxide in cardiovascular diseases. Mol Aspects Med 2005;26:33-65.

30. Ginnan R, Guikema BJ, Halligan KE, Singer HA, Jourd'heuil D. Regulation of smooth muscle by inducible nitric oxide synthase and NADPH oxidase in vascular proliferative diseases. Free Radic Biol Med 2008;44: 1232-45.

31. Zuckerbraun BS, Stoyanovsky DA, Sengupta R, et al. Nitric oxide-induced inhibition of smooth muscle cell proliferation involves S-nitrosation and inactivation of RhoA. Am J Physiol Cell Physiol 2007;292:C824-31.

32. McElroy B, Powell JC, McCarthy JV. The insulin-like growth factor 1 (IGF1) receptor is a substrate for gamma-secretase-mediated intramembrane proteolysis. Biochem Biophys Res Commun 2007;358:1136-41.

33. Bian K, Doursout MF, Murad F. Vascular system: role of nitric oxide in cardiovascular diseases. J Clin Hypertens (Greenwich) 2008;10:304-10. 